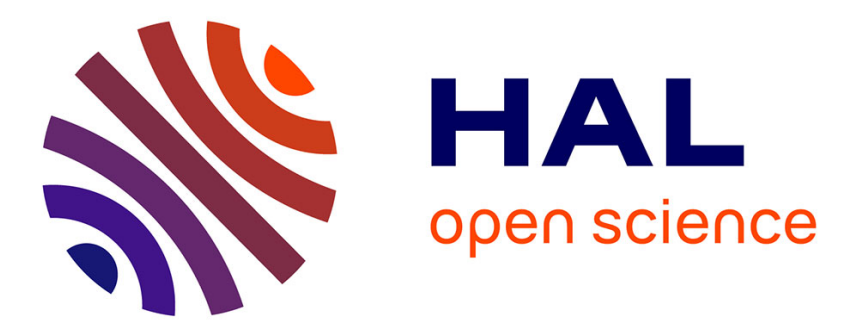

\title{
Structure development in a soft cheese curd model during manufacture in relation to its biochemical characteristics
}

Rachel Boutrou, Marie-Hélène Famelart, Frederic Gaucheron, Yvon Le Graet, Jean-Yves Gassi, Michel Piot, Joelle Léonil

\section{To cite this version:}

Rachel Boutrou, Marie-Hélène Famelart, Frederic Gaucheron, Yvon Le Graet, Jean-Yves Gassi, et al.. Structure development in a soft cheese curd model during manufacture in relation to its biochemical characteristics. Journal of Dairy Research, 2002, 69 (4), pp.605-618. hal-02263112

\section{HAL Id: hal-02263112 \\ https://hal.science/hal-02263112}

Submitted on 2 Aug 2019

HAL is a multi-disciplinary open access archive for the deposit and dissemination of scientific research documents, whether they are published or not. The documents may come from teaching and research institutions in France or abroad, or from public or private research centers.
L'archive ouverte pluridisciplinaire HAL, est destinée au dépôt et à la diffusion de documents scientifiques de niveau recherche, publiés ou non, émanant des établissements d'enseignement et de recherche français ou étrangers, des laboratoires publics ou privés. 
Journal of Dairy Research (2002) 69 605-618. (C) Proprietors of Journal of Dairy Research 2002

\title{
Structure development in a soft cheese curd model during manufacture in relation to its biochemical characteristics
}

\author{
BY RACHEL BOUTROU*, MARIE-HELENE FAMELART, \\ FREDERIC GAUCHERON, YVON LE GRAET, JEAN-YVES GASSI, \\ MICHEL PIOT AND JOELLE LEONIL \\ INRA, Laboratoire de Recherches de Technologie Laitière, 65 rue de Saint-Brieuc, \\ 35042, Rennes, France
}

(Received 10 July 2001 and accepted for publication 19 February 2002)

\begin{abstract}
Summary. The structure development of a soft cheese curd model has been studied in relationship to its rheological properties and its biochemical characteristics $(\mathrm{pH}$, amount and partition of minerals, casein proteolysis) at different technical steps including cutting, drawing, three turns and demoulding. Scanning electron microscopy was used to observe structural changes during the drainage of a fat-free soft cheese. The micrographs provided visual evidence of changes in the casein matrix from casein particles aggregated in clusters to uniform strands observed at the demoulding. The initial increase of loss tangent and of the exponent of the power law between $G^{\prime}$ and $G^{\prime \prime}$ and frequency (that were maximal at the second turn) was related to the solubilization of micellar calcium phosphate, while intact caseins and large casein fragments accumulated in the curd. After the second turn, the strength, Youngs' and loss moduli of the curd increased greatly. The hydrolysis of $\alpha_{\mathrm{s} 1}$-casein into $\alpha_{\mathrm{S} 1}-\mathrm{I}-\mathrm{CN}$ f(24-199) may facilitate the rearrangement of casein particles within the curd. The $\mathrm{pH}$-induced solubilization of calcium phosphate continued throughout the manufacture process but was unexpectedly incomplete at the end of the drainage. Combination of electron microscopic observations with dynamic rheological measurements and chemical and biochemical assessments provided increased knowledge about the structure of soft cheese during drainage, an important but poorly understood cheese making stage.
\end{abstract}

KEYwORDS: Structure, soft cheese, drainage, minerals, proteolysis.

During the manufacture of soft cheese, formation of curd results initially from the coagulation by rennet of a pre-acidified milk, and subsequently from drainage of the curd, leading to concentration of the casein. The basic chemistry and physics behind aggregation of casein, gel formation and syneresis have been reviewed (Mietton et al. 1994; Lomholt \& Qvist, 1999). Curd formation is important for controlling the structure, moisture content and rheological properties of the cheese and thus its texture.

Curd consists of a casein matrix that retains fat and to a greater or lesser extent the whey, during the drainage. Curd is further brined and ripened to gain the desired organoleptic properties arising from the many diverse enzymatic reactions that lead

\footnotetext{
* For correspondence; e-mail: rboutrou@rennes.inra.fr
} 
to a mature cheese. As an example, the chemical composition of Camembert curd and the subsequent changes caused by the metabolism of surface flora such as Penicillium camemberti, together with the ripening conditions, determine the structure and consequently the texture of the mature cheese.

Rennet coagulation, acidification and drainage are the three complex phenomena which have been each extensively studied. But these phenomena have rarely been studied together despite their interdependence during curd formation. To date, extended studies on structure development in curd concerned few cheeses, among them Mozzarella cheese (Oberg et al. 1993). However, to understand and thereafter to control the manufacturing process of cheese, it is essential to find out how the structure of the curd developed and gained its particular properties. On one hand, the change in macro- and microstructure of the curd during manufacture can be observed; on the other hand, the chemical and physical parameters that are driving this change can be understood (McMahon \& Oberg, 1999). Theses changes essentially deal with $\mathrm{pH}$, content and partition of minerals, water content and proteolysis.

The aim of this work was to relate the biochemical changes during the formation of a soft cheese curd model to the structure of the curd observed using scanning electronic microscopic and rheological methods. This fat-free model includes filtered skim milk inoculated with a single lactococcal strain as starter used in order to better understand the structure development of the casein matrix.

\section{MATERIALS AND METHODS}

\section{Manufacture of model soft cheese}

Soft cheese curds were made in triplicate according to the process used to manufacture Camembert cheese with a pilot plant (Tecnal, F-79024 Niort, France). Raw skim milk $(46 \mathrm{~kg})$ was micro-filtered at $35{ }^{\circ} \mathrm{C}$ through a $1 \cdot 4-\mu \mathrm{m}$ Sterilox membrane (Société des Céramiques Techniques, F-65460 Bazet, France). This process allows milk filtration with bacterial retention rates of the contaminant flora in the discarded retentate above $99.9 \%$ (Trouvé et al. 1991). The milk was inoculated with Lactococcus lactis subsp. cremoris AM2, a laboratory strain having high proteolytic activity and high ability to lyse (Boutrou et al. 1998). This lactococcal starter was cultured three times in sterile reconstituted skim milk at $30{ }^{\circ} \mathrm{C}$ and used to inoculate the micro-filtered milk at $34{ }^{\circ} \mathrm{C}$ at the rate of $15 \mathrm{ml}$ inoculum/l milk. Renneting was carried out at $\mathrm{pH} 6.35$ using $20 \mathrm{mg}$ pure recombined chymosin (EC 3.4.23.4.; Maxiren 50, Gist Brocades, F-59472 Seclin, France)/l milk. At $31.5 \mathrm{~min}$ $(3 \times$ the average clotting time of $10.5 \mathrm{~min})$, the coagulum was cut in $1.5 \times 1.5 \times 1.7 \mathrm{~cm}$ cubes and gently stirred 10 and 25 min after cutting to prevent cubes from sticking together. Ten kilograms whey were drawn off (i.e. $22 \%$ of total cheese-milk weight) and the curd was poured out into $10 \cdot 8-\mathrm{cm}$ diameter moulds. The moulds were turned three times 15, 3 and $6 \mathrm{~h}$ after renneting and removed after $20 \mathrm{~h}$. The room temperature was controlled at $34{ }^{\circ} \mathrm{C}$ from coagulation to drawing, $26{ }^{\circ} \mathrm{C}$ at moulding, $24^{\circ} \mathrm{C}$ at the first turn, $22{ }^{\circ} \mathrm{C}$ at the second turn, and $18{ }^{\circ} \mathrm{C}$ from the third turn to demoulding. Some curds were collected at each processing step and analysed immediately (bacterial numeration, microscopic and rheological analyses) or quickly frozen at $-20^{\circ} \mathrm{C}$ until required for biochemical analysis. An additional manufacture without curd sampling was performed in order to estimate the actual quantity of whey expelled. 


\section{Bacterial numeration}

Curd sample $(10 \mathrm{~g})$ was homogenized with a Warring Blender (Labo-Standa, F-14000 Caen, France) for $1 \mathrm{~min}$ at $13500 \mathrm{rpm}$ in $90 \mathrm{ml} 20 \mathrm{~g} / \mathrm{l}$ sodium citrate. The lactococci were numerated on lactose M17 agar plates after $48 \mathrm{~h}$ incubation at $30^{\circ} \mathrm{C}$.

Scanning electron microscopy

From the curd centre, $2 \times 2 \times 3 \mathrm{~mm}$ pieces of curd were taken in the vertical direction, and immediately fixed in $0 \cdot 1 \mathrm{M}$-sodium cacodylate, $\mathrm{pH} 7 \cdot 2$ containing $25 \mathrm{ml}$ glutaraldehyde $/ \mathrm{l}$ at $4{ }^{\circ} \mathrm{C}$ for $24 \mathrm{~h}$. After rinsing with cacodylate and water, pieces were dehydrated in alcohol series and critical point dried. Fractured samples were glued on the sample holder, gold coated and observed at $10 \mathrm{kV}$ on a Philips XL20 scanning electron microscope (FEI Philips Electronique, F-93000 Bobigny, France). At least five micrographs were taken at each technological step on the three cheese manufactures. This kind of preparation has been widely used either on acid gels (Famelart et al. 1996) or on cheeses (Emmons et al. 1980; Rousseau \& Le Gallo, 1990; Haque et al. 1997) except that we did not post-fix in osmium tetraoxide. This latter step is only required when fat is present. According to Rousseau \& Le Gallo (1990), fixation in glutaraldehyde maintains the network structure and the observed aspect of micelles agrees with previous descriptions. Emmons et al. (1980) reported a good agreement of the Cheddar cheese structure observed by this preparation and thin-section electron microscopy.

\section{Rheological properties}

Uniaxial compression. Curds under drainage at the first, second and third turn and at demoulding were rapidly cut at $30 \mathrm{~mm}$ height in such a manner that the lower part of the curd before each turn was discarded. At demoulding, the curd height was $30 \mathrm{~mm}$. Uniaxial compression was performed at room temperature at $120 \mathrm{~mm} / \mathrm{min}$ with an Instron Universal testing machine 4501 (Instron S.A., F-78284 Guyancourt, France), using a 35-mm diameter plate and a 100-N (1000 N for the sample at the end of drainage) load cell. Many authors used a compression speed of $30 \mathrm{~mm} / \mathrm{min}$, but a higher speed allowed a faster compression of the sample of soft cheese as used by Kfoury et al. (1989) and Mpagana \& Hardy (1986) on Camembert cheese. Indeed, the sample was clearly draining during storage. As the size of the measuring probe was smaller than the curd sample, the measurements were not absolute rigidity measurements, but they could be compared with each other. Although the results were not expressed in stress and strain data for simpler calculations, they could be compared with trends in other cheeses. A mean temperature of the sample between 22 and $27^{\circ} \mathrm{C}$ was assumed, from its own initial temperature and the temperature losses during preparation in the $22-{ }^{\circ} \mathrm{C}$ Instron room. Rheological measurements were not corrected for the effect of temperature. The strength at $5 \mathrm{~mm}$, the displacement and the force at rupture and the Young's modulus were recorded. Strengths at 5, 10 and $15 \mathrm{~mm}$ were initially collected and showed the same trend.

Harmonic measurements. From the same piece of curd as the one used for uniaxial compression, a 40-mm diameter sample was cut using a borer, in the vertical direction. With an apparatus equipped with two wires, $4 \mathrm{~mm}$-high slices were cut. Just after cutting, the slice was placed between two cross-hatched parallel plates at $26{ }^{\circ} \mathrm{C}$. The temperature was chosen as the average temperature of the curd during the whole draining process and was probably the least disturbing testing condition. An aluminium solvent trap cover was placed above the upper plate to prevent 
evaporation. A logarithmic frequency sweep $(0 \cdot 5-10 \mathrm{~Hz})$ at $2 \%$ strain was performed with 10 points per frequency-decade. Conditions were adapted from previous studies (Horne et al. 1993; Solorza \& Bell, 1995). The frequency range was reduced to reach a shorter time for the whole sweep and strain at $2 \%$ was in the linear region. The slope of the loss modulus and the storage modulus versus frequency in a log-log representation (respectively $\exp G^{\prime}$ and $\exp G^{\prime \prime}$ ) was collected, together with the mean loss and storage moduli and the mean loss angle (delta).

\section{Biochemical analysis}

The $\mathrm{pH}$ of the curd was measured using a penetrating electrode (Ingold) linked to a Hi $9025 \mathrm{pH}$-meter. Total solids (TS) of grated cheese was determined after desiccation at $102-105^{\circ} \mathrm{C}$ for $7 \mathrm{~h}$ (International Dairy Federation, 1982). The lactose concentration was determined by ion chromatography as described by Morgan et al. (1999).

For the determination of mineral content in the curd, $3 \mathrm{~g}$ curd was homogenized in $100 \mathrm{~g} 0.02 \mathrm{M}$-nitric acid solution. The homogenate obtained had a $\mathrm{pH} \approx 3$ leading to total mineral solubilization. After standing $1 \mathrm{~h}$ at room temperature, the solution was filtered through a $0 \cdot 42-\mu \mathrm{m}$ filter (Minisart, Sartorius, D-37070 Göttingen, Germany). To estimate the proportion of mineral associated with the casein matrix, the mineral content in the aqueous phase of the curd was also determined. About $30 \mathrm{~g}$ curd was centrifuged at $3000 \mathrm{~g}$ for $30 \mathrm{~min}$, and the supernatant was filtered through a $0.42-\mu \mathrm{m}$ filter. The aqueous phase of the milk was obtained by centrifugation of milk at $1800 \mathrm{~g}$ for $30 \mathrm{~min}$, ultrafiltration of the supernatant on an Ultrafree 15 membrane (molecular mass cut-off 10000 Da) (Millipore, F-78280 Saint Quentin en Yvelines, France) and filtration through a $0 \cdot 42-\mu \mathrm{m}$ filter.

Cation (calcium, magnesium, sodium and potassium) and anion (lactate, chloride, inorganic phosphate, citrate) concentrations were determined on $0 \cdot 42-\mu \mathrm{m}$ filtrates using atomic absorption spectrometry (Varian AA300 spectrometer, F-91941 Les Ulis, France) (Brulé et al. 1974) and ion chromatography (Dionex, F-78354 Jouy-enJosas, France) (Gaucheron et al. 1996), respectively. Concentrations were expressed in $\mathrm{g} / \mathrm{kg}$. From the calcium and inorganic phosphate concentrations in the curd and in its corresponding aqueous phase, the percentage of ions still associated to the casein matrix was calculated as follows:

$\%$ associated $=$

$$
100 \times\left(1-\left(\frac{\text { mineral content in the aqueous phase } /\left(1000-\mathrm{TS}_{\text {aqueous phase }}\right)}{\text { mineral content in the curd } /\left(1000-\mathrm{TS}_{\text {curd }}\right)}\right)\right) .
$$

From the mineral content (calcium, magnesium, sodium, potassium, lactate, chloride, inorganic phosphate and citrate) determined in the aqueous phase of the curd, a computer program calculated the mineral partitions and the activities of each ion and the ionic strength (Holt et al. 1981). From activities, the solubility product for brushite was calculated. Brushite was chosen because several authors found, in milk, an invariant ion activity product to be approximately that of a dicalcium phosphate (Holt, 1982; Chaplin, 1984). The calculations were carried out in the $\mathrm{pH}$ range where calcium phosphate salts were still at least partially in the micellar phase ( $\mathrm{pH}$ between 6.7 and $\approx 4 \cdot 8$ ). The results of these theoretical calculations were of semi-quantitative significance as assumed by Morris et al. (1988).

For the determination of nitrogen content of the curd, an aliquot of grated curd was suspended in a sodium citrate solution as described by Gripon (1975). The 
content of total nitrogen (TN), $\mathrm{pH} 4 \cdot 6$ soluble nitrogen (SN) and non-protein nitrogen (NPN) soluble in $12 \%$ trichloroacetic acid were determined in duplicate by the Kjeldahl method.

Urea-PAGE containing $180 \mathrm{~g}$ acrylamide/l in $4.33 \mathrm{~m}$-urea-0.0375 M-Tris-HCl buffer, $\mathrm{pH} 8.8$ was used in a Mini Protean II gel system (BioRad, F-94203 Ivry-surSeine, France) according to the method of Andrews (1983). Insoluble fraction of the curd was prepared. Sodium citrate solution of cheese obtained as previously described, was centrifuged at $10000 \mathrm{~g}$ at $20^{\circ} \mathrm{C}$ for $10 \mathrm{~min}$ and the pellet was resuspended to the initial volume with $8 \cdot 75$ m-urea. Samples were denatured with $0 \cdot 0625 \mathrm{M}$-Tris- $\mathrm{HCl}$ buffer, $\mathrm{pH} 6 \cdot 8$, containing, $3 \cdot 3 \mathrm{M}$-urea, $50 \mathrm{ml} \beta$-mercaptoethanol/l, $100 \mathrm{ml}$ glycerol/1 and $0.5 \mathrm{~g}$ bromophenol blue/l. A volume of the insoluble fraction equivalent to $10 \mu \mathrm{g}$ TN measured in the curd was loaded by lane. Migration was for $2.5 \mathrm{~h}$ at $20^{\circ} \mathrm{C}$ and $200 \mathrm{~V}$ constant voltage. The protein bands were revealed with $\mathrm{R}_{250}$ Coomassie blue staining.

\section{RESULTS}

\section{Drainage, acidification, lactose fermentation and bacterial growth}

After renneting, the $\mathrm{pH}$ of the curd continued to decrease until $\mathrm{pH} 4.8$ at demoulding (Table 1). The major part of whey $(76 \mathrm{~kg} / 100 \mathrm{~kg}$ milk) was drained before the first turn. Thereafter, whey continued to be expelled, but the quantity decreased drastically, especially from the second turn to demoulding (Table 1). As the times of the successive turns were $1 \cdot 5,3$ and $6 \mathrm{~h}$ after renneting, the changes with time of expelled whey were very tiny.

Bacterial growth was concomitant with the decrease of lactose concentration and the proportional increase in lactate concentration (Table 2). The Lc. lactis AM2 grew slowly within the curd during the drainage (Table 1 ). The bacteria were visible by electron microscopy from the first turn to the end of the drainage, either alone or dividing (Fig. 1). No evidence was found of bacteria connected to the casein matrix. They appeared more in void spaces, surrounded by whey, as in Cheddar cheese (Haque et al. 1997), in Cottage cheese (Kalab, 1978) or in yogurt (Kalab, 1979; Kalab et al. 1983; Tamime et al. 1984).

\section{Scanning electron microscopic observations}

Electron microscopy was used to visualize the structure of the curd at different steps in the manufacturing process. The micrograph presented at each step is representative of the three cheeses manufactured (Fig. 1). Water was removed during sample drying, leaving only the casein matrix and bacteria to be visualized. Open spaces, that contained the aqueous phase before sample drying, were always uniformly dispersed and of the same size throughout the drainage. Observed particles supposed to be micelle aggregates (about $0 \cdot 25-0.5 \mu \mathrm{m}$ ) agglomerated to form clusters $(0 \cdot 5-4 \cdot 0 \mu \mathrm{m})$ that were visible at the first turn. There were still strands connected to the rest of the network at one end only (Fig. $1 a$ ). Holes between 2 and $6 \mu \mathrm{m}$ showed the pores of the matrix. Particles within the clusters rearranged into chains but the micelle-based structure was still visible at the second turn (Fig. 1b). At the third turn, initial particles became difficult to visualize and the fusion between particles progressed, thus thickening and smoothing the strands (Fig. 1c) until the curd had lost the cluster structure leading to the completely fused amorphous network at demoulding (Fig. $1 d$ ). The chains observed at demoulding had a diameter $\approx 0 \cdot 6-1 \cdot 5 \mu \mathrm{m}$ and were larger than the average diameter of individual particles at the first turn. This is particularly evident while comparing with lactococci cells. 
Table 1. Characterization and rheological properties of the milk and the curd throughout drainage. Cheese was prepared on three separate occasions

(Values are mean $\pm \mathrm{sD}$ for $n=3$ or various $\S$ )

\begin{tabular}{|c|c|c|c|c|c|c|}
\hline & Milk & Cutting & 1st turn & 2nd turn & 3rd turn & Demoulding \\
\hline $\begin{array}{l}\text { Whey expelled } \dagger \\
\mathrm{kg} / 100 \mathrm{~kg} \text { milk }\end{array}$ & - & $0 \cdot 0$ & $76 \cdot 0$ & $86 \cdot 8$ & $89 \cdot 5$ & $90 \cdot 5$ \\
\hline $\begin{array}{l}\text { Whey expelled } \$ \\
\text { kg/100 kg milk }\end{array}$ & - & $0 \cdot 0 \pm 0 \cdot 0$ & $73 \cdot 8 \pm 0 \cdot 92$ & $82 \cdot 2 \pm 0 \cdot 67$ & $84 \cdot 2 \pm 0 \cdot 72$ & $85 \cdot 3 \pm 1 \cdot 12$ \\
\hline $\mathrm{PH}$ & $6 \cdot 56 \pm 0 \cdot 01$ & $6 \cdot 22 \pm 0 \cdot 03$ & $5 \cdot 91 \pm 0 \cdot 06$ & $5 \cdot 23 \pm 0 \cdot 09$ & $4 \cdot 95 \pm 0 \cdot 06$ & $4 \cdot 83 \pm 0 \cdot 06$ \\
\hline Temperature, ${ }^{\circ} \mathrm{C}$ & $34 \cdot 4 \pm 0 \cdot 17$ & $34 \cdot 0 \pm 0 \cdot 15$ & $31 \cdot 8 \pm 0 \cdot 25$ & $27.7 \pm 0.85$ & $20.9 \pm 0.93$ & $16 \cdot 5 \pm 0 \cdot 47$ \\
\hline Strength at $5 \mathrm{~mm}, \mathrm{~N}$ & 二 & 二 & $3 \cdot 67 \pm 0 \cdot 74^{(9)}$ & $6 \cdot 92 \pm 0 \cdot 74^{(9)}$ & $16 \cdot 91 \pm 2 \cdot 05^{(9)}$ & $53 \cdot 07 \pm 11 \cdot 19^{(19)}$ \\
\hline Young's modulus, $\mathrm{Pa}$ & - & - & $32566 \pm 5629$ & $59039 \pm 7178$ & $152611 \pm 11609$ & $576403 \pm 91101$ \\
\hline $\exp G^{\prime \prime}$ & - & - & $0 \cdot 23 \pm 0 \cdot 0057$ & $0 \cdot 23 \pm 0.003$ & $0 \cdot 22 \pm 0 \cdot 0041$ & $0 \cdot 21 \pm 0 \cdot 0047$ \\
\hline Loss angle, degree & - & - & $18 \cdot 95 \pm 0 \cdot 30$ & $21 \cdot 11 \pm 0 \cdot 32$ & $20 \cdot 07 \pm 0 \cdot 16$ & $17 \cdot 86 \pm 0 \cdot 28$ \\
\hline Cell count, $\log \mathrm{cfu} / \mathrm{ml}$ & $6 \cdot 59 \pm 0 \cdot 45$ & $6 \cdot 93 \pm 0 \cdot 37$ & $8.54 \pm 0.08$ & $8.72 \pm 0.46$ & $9 \cdot 00 \pm 0 \cdot 3$ & $9 \cdot 11 \pm 0 \cdot 46$ \\
\hline
\end{tabular}

$\dagger$ Without curd sampling (one manufacture)

$\$$ With curd sampling (three manufactures).

Superscript numbers in parentheses indicate the total number of measurements for either compression or oscillation tests. 
Table 2. Biochemical properties of the milk, the curd and its aqueous phase throughout drainage. The results determined in the aqueous phase either of the milk or of the curd (supernatant of centrifugation as described in $M \& M$ ) are denoted by ${ }^{a q u}$

(Values are means \pm SD for replicates form three cheese-making trials)

\begin{tabular}{|c|}
\hline $\begin{array}{l}\text { Calcium } \\
\text { Calcium } \\
\text { aqu }\end{array}$ \\
\hline Magnesium \\
\hline Magnesium ${ }^{\text {aqu }}$ \\
\hline Sodium \\
\hline Sodium ${ }^{\text {aqu }}$ \\
\hline Potassium \\
\hline Potasium ${ }^{\text {aqu }}$ \\
\hline Inorganic phosphate \\
\hline Inorganic phosphate ${ }^{\text {aqu }}$ \\
\hline Citrate $^{\text {aqu }}$ \\
\hline Chloride $^{\text {aqu }}$ \\
\hline Lactate $^{\text {aqu }}$ \\
\hline $\begin{array}{l}\text { Log solubility product } \\
\text { brushite }^{\text {aqu }} \text { (no unit) }\end{array}$ \\
\hline Ionic strength ${ }^{\text {aqu }}(\mathrm{mM})$ \\
\hline Lactose $^{\text {aqu }}$ \\
\hline TS \\
\hline TN \\
\hline SN \\
\hline $\begin{array}{l}\mathrm{NPN} \\
\mathrm{TN}-\mathrm{SN}\end{array}$ \\
\hline
\end{tabular}

$\begin{array}{ccc}\text { Milk } & \text { Cutting } & 1 \text { st turn } \\ 1 \cdot 32 \pm 0 \cdot 03 & 1 \cdot 46 \pm 0 \cdot 09 & 4 \cdot 68 \pm 0 \cdot 18 \\ 0 \cdot 37 \pm 0 \cdot 02 & 0 \cdot 48 \pm 0 \cdot 01 & 1 \cdot 06 \pm 0 \cdot 2 \\ 0 \cdot 12 \pm 0 \cdot 01 & 0 \cdot 12 \pm 0 \cdot 01 & 0 \cdot 22 \pm 0 \cdot 01 \\ 0 \cdot 07 \pm 0 \cdot 01 & 0 \cdot 09 \pm 0 \cdot 01 & 0 \cdot 12 \pm 0 \cdot 01 \\ 0 \cdot 42 \pm 0 \cdot 01 & 0 \cdot 49 \pm 0 \cdot 02 & 0 \cdot 48 \pm 0 \cdot 06 \\ 0 \cdot 41 \pm 0 \cdot 01 & 0 \cdot 44 \pm 0 \cdot 01 & 0 \cdot 47 \pm 0 \cdot 02 \\ 1 \cdot 72 \pm 0 \cdot 05 & 1 \cdot 77 \pm 0 \cdot 08 & 1 \cdot 74 \pm 0 \cdot 18 \\ 1 \cdot 55 \pm 0 \cdot 03 & 1 \cdot 66 \pm 0 \cdot 02 & 1 \cdot 76 \pm 0 \cdot 03 \\ \text { nd } & 2 \cdot 41 \pm 0 \cdot 21 & 5 \cdot 57 \pm 0 \cdot 23 \\ 0 \cdot 99 \pm 0 \cdot 03 & 1 \cdot 13 \pm 0 \cdot 02 & 1 \cdot 75 \pm 0 \cdot 24 \\ 1 \cdot 66 \pm 0 \cdot 09 & 1 \cdot 72 \pm 0 \cdot 08 & 1 \cdot 71 \pm 0 \cdot 09 \\ 1 \cdot 11 \pm 0 \cdot 04 & 1 \cdot 11 \pm 0 \cdot 08 & 1 \cdot 04 \pm 0 \cdot 05 \\ \text { nd } & 0 \cdot 66 \pm 0 \cdot 02 & 3 \cdot 50 \pm 0 \cdot 77 \\ - & -6 \cdot 24 & -5 \cdot 85 \\ & & 108 \\ 64 & 71 & 47 \cdot 29 \pm 0 \cdot 43 \\ \text { nd } & 49 \cdot 61 \pm 1 \cdot 82 & \text { nd } \\ 89 \cdot 86 \pm 0 \cdot 45 & 60 \cdot 49 \pm 13 \cdot 93 & 165 \cdot 21 \pm 11 \cdot 07 \\ 33 \cdot 58 \pm 0 \cdot 31 & 9 \cdot 85 \pm 0 \cdot 79 & 11 \cdot 58 \pm 0 \cdot 79 \\ 8 \cdot 00 \pm 0 \cdot 36 & 1 \cdot 78 \pm 0 \cdot 82 & 2 \cdot 79 \pm 0 \cdot 41 \\ 1 \cdot 67 \pm 0 \cdot 17 & 50 \cdot 64 & 153 \cdot 63 \\ 25 \cdot 6 & & \end{array}$

2nd turn
$6 \cdot 20 \pm 0 \cdot 77$
$3 \cdot 35 \pm 0 \cdot 17$
$0 \cdot 26 \pm 0 \cdot 02$
$0 \cdot 21 \pm 0 \cdot 01$
$0 \cdot 47 \pm 0 \cdot 03$
$0 \cdot 52 \pm 0 \cdot 02$
$1 \cdot 61 \pm 0 \cdot 24$
$1 \cdot 80 \pm 0 \cdot 07$
$7 \cdot 01 \pm 0 \cdot 68$
$4 \cdot 22 \pm 0 \cdot 16$
$2 \cdot 15 \pm 0 \cdot 12$
$0 \cdot 99 \pm 0 \cdot 04$
$11 \cdot 34 \pm 0 \cdot 74$
$-5 \cdot 87$

217
$35 \cdot 8 \pm 1 \cdot 23$
$279 \cdot 69 \pm 4 \cdot 01$
$215 \cdot 80 \pm 4 \cdot 04$
$13 \cdot 3 \pm 0 \cdot 74$
$4 \cdot 36 \pm 0 \cdot 45$
$202 \cdot 49$
3rd turn
$6 \cdot 20+0 \cdot 7$
$5 \cdot 08 \pm 0 \cdot 11$
$0 \cdot 25 \pm 0 \cdot 01$
$0 \cdot 26 \pm 0 \cdot 01$
$0 \cdot 48 \pm 0 \cdot 07$
$0 \cdot 51 \pm 0 \cdot 02$
$1 \cdot 66 \pm 0 \cdot 37$
$1 \cdot 87 \pm 0 \cdot 07$
$7.09 \pm 0.71$
$709 \pm 0$
$2 \cdot 55 \pm 0 \cdot 13$
$2 \cdot 55 \pm 0 \cdot 13$
$0 \cdot 99 \pm 0 \cdot 04$
$+1 \cdot 4$
$-5 \cdot 75$

284
$28 \cdot 41+1 \cdot 63$

$28 \cdot 41 \pm 1 \cdot 63$
$308 \cdot 25 \pm 4 \cdot 80$

$308 \cdot 25 \pm 4 \cdot 80$
$243.53 \pm 2 \cdot 7$

$243 \cdot 53 \pm 2 \cdot 72$
$13 \cdot 78+0 \cdot 79$

$5 \cdot 45 \pm 0.38$

$229 \cdot 75$

$$
\begin{gathered}
\text { Demoulding } \\
6 \cdot 44 \pm 0 \cdot 23 \\
7 \cdot 15 \pm 0 \cdot 15 \\
0 \cdot 33 \pm 0 \cdot 01 \\
0 \cdot 31 \pm 0 \cdot 01 \\
0 \cdot 41 \pm 0 \cdot 03 \\
0 \cdot 52 \pm 0 \cdot 02 \\
1 \cdot 57 \pm 0 \cdot 30 \\
1 \cdot 93 \pm 0 \cdot 09 \\
8 \cdot 35 \pm 2 \cdot 48 \\
8 \cdot 48 \pm 0 \cdot 48 \\
3 \cdot 06 \pm 0 \cdot 16 \\
1 \cdot 01 \pm 0 \cdot 02 \\
23 \cdot 44 \pm 2 \cdot 60 \\
-5 \cdot 68
\end{gathered}
$$

$$
363
$$

$19 \cdot 38 \pm 2 \cdot 51$

$330 \cdot 25 \pm 55 \cdot 03$

$268 \cdot 44 \pm 30 \cdot 90$

$18 \cdot 59 \pm 3 \cdot 61$

$7 \cdot 68 \pm 2 \cdot 05$

$249 \cdot 85$

nd, not determined.

$\uparrow$ Concentrations $(\mathrm{g} / \mathrm{kg})$ measured in the aqueous phase of either milk or curd (supernatant from centrifugation as described in M\&M) are denoted by ${ }^{\text {aqu }}$

TN, total nitrogen; TS, total solids; SN, soluble nitrogen; NPN, non-protein nitrogen; TN-SN, estimated casein concentration. 
A
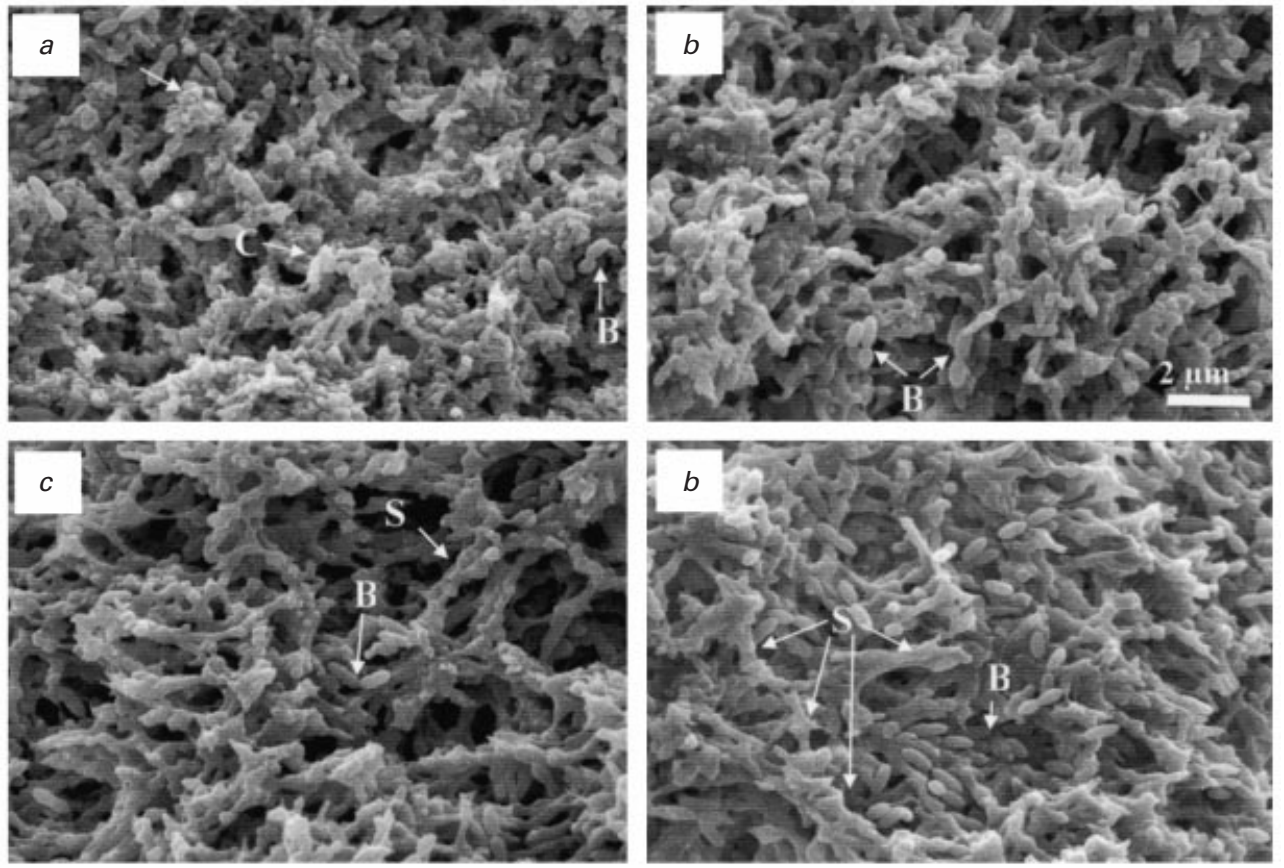

B
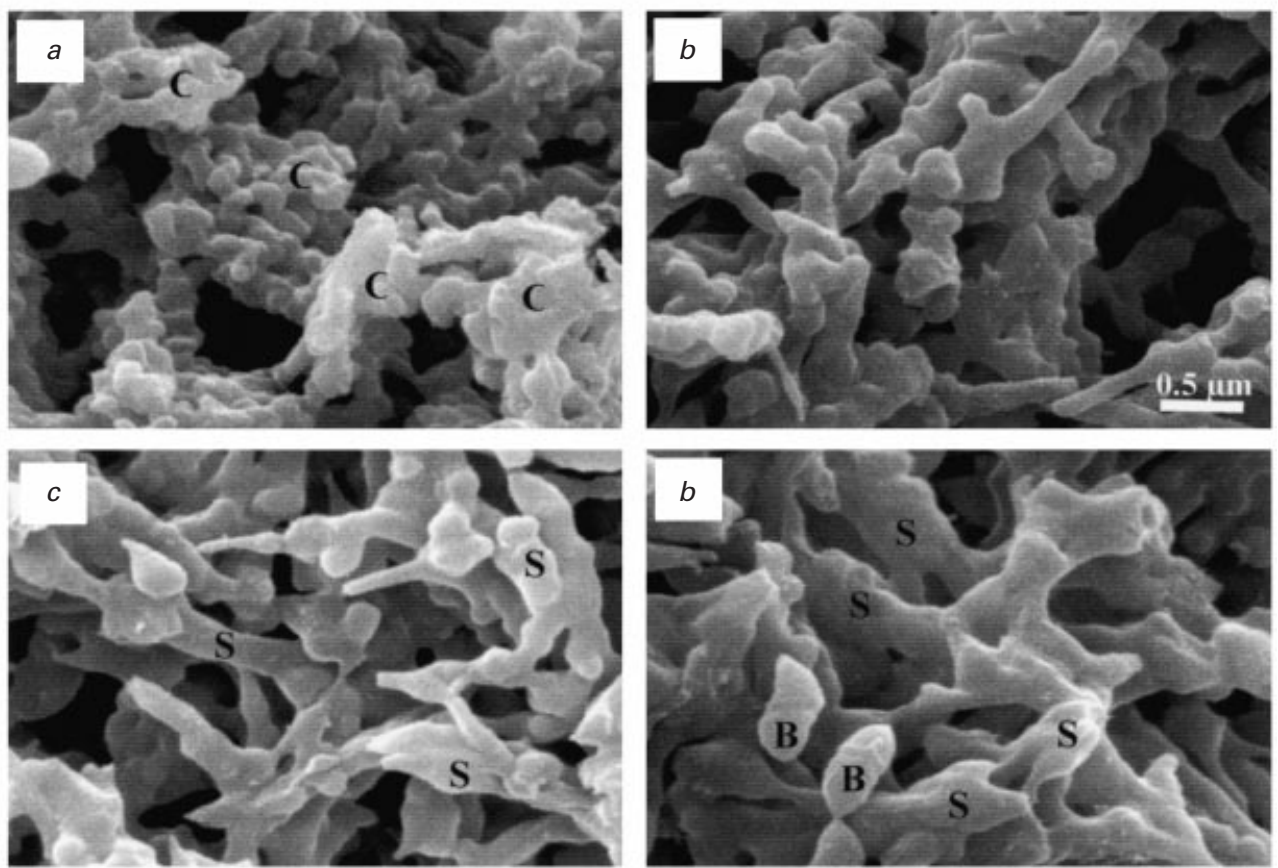

Fig. 1. Scanning electron micrographs of curd at $(a)$, the first turn $(b)$, second turn $(c)$, third turn and $(d)$, at demoulding with magnification $\times 5000(\mathrm{~A})$ and $\times 20000(\mathrm{~B}) . \mathrm{B}=$ bacteria, $\mathrm{S}=$ strands, $\mathrm{C}=$ cluster of particles. 


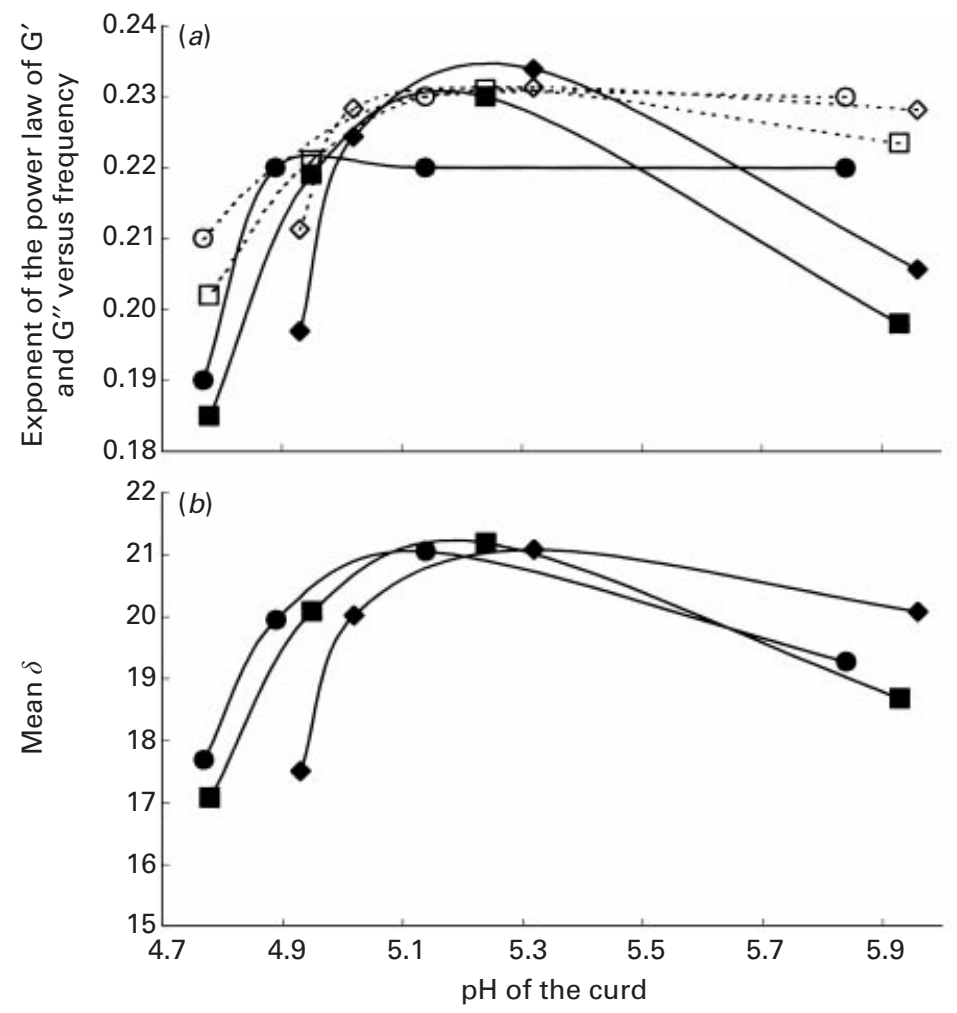

Fig. 2. (a) Relation between the $\mathrm{pH}$ of the curd and the exponent of the power law of $\mathrm{G}^{\prime}$ $\mathrm{G}^{\prime \prime}(\bigcirc, \diamond, \square)$ versus the frequency; $(b)$ mean value of loss angle $(\bullet, \bullet)$ versus the $\mathrm{pH}$ of the curd. The three different symbols are for the triplicate manufactures.

\section{Rheological properties}

The compression curves of curd under drainage were obtained with relatively constant slopes between the force and the displacement. A rupture was observed on the compression curves only at the third turn and at the demoulding. The displacement and the force at rupture were $14-16 \mathrm{~mm}$ and $56-74 \mathrm{~N}$ for the third turn and 10-12 mm and 120-165 $\mathrm{N}$ for demoulding (results not shown). This means a higher brittleness of the curd while draining.

The Young's modulus and the force at $5 \mathrm{~mm}$ compression increased 2, 5 and 16 times relative to values at the first turn, for the second turn, third turn and demoulding, respectively. At the same times, $\mathrm{G}^{\prime}$ and $\mathrm{G}^{\prime \prime}$ moduli increased 2, 3 and 8 times on average (Table 1 ). The increase of $G^{\prime \prime}$ was greater at the second and third turn and lower at demoulding, compared with $\mathrm{G}^{\prime}$. The slopes of the log modulus - log frequency curves $\left(\exp \mathrm{G}^{\prime}, \exp \mathrm{G}^{\prime \prime}\right)$ and the loss angle values were calculated. $\exp \mathrm{G}^{\prime}$ and $\exp \mathrm{G}^{\prime \prime}$ increased at the second and third turn and decreased at demoulding. This indicates a more liquid-like material at the second and third turns and a more solidlike material at demoulding; firmness of the curd increased weakly before the third turn and strongly after.

A power law dependence of the rheological characteristics such as the strength measured at $5 \mathrm{~mm}$ on the casein concentration (estimated as TN-SN) was found with exponent values of $1 \cdot 30$ [strength $=$ constant $\left.\times(\mathrm{TN}-\mathrm{SN})^{1 \cdot 30}\right]$. Similarly the Young's modulus, $G^{\prime}$ and $G^{\prime \prime}$ depended on the casein concentration with a power law 


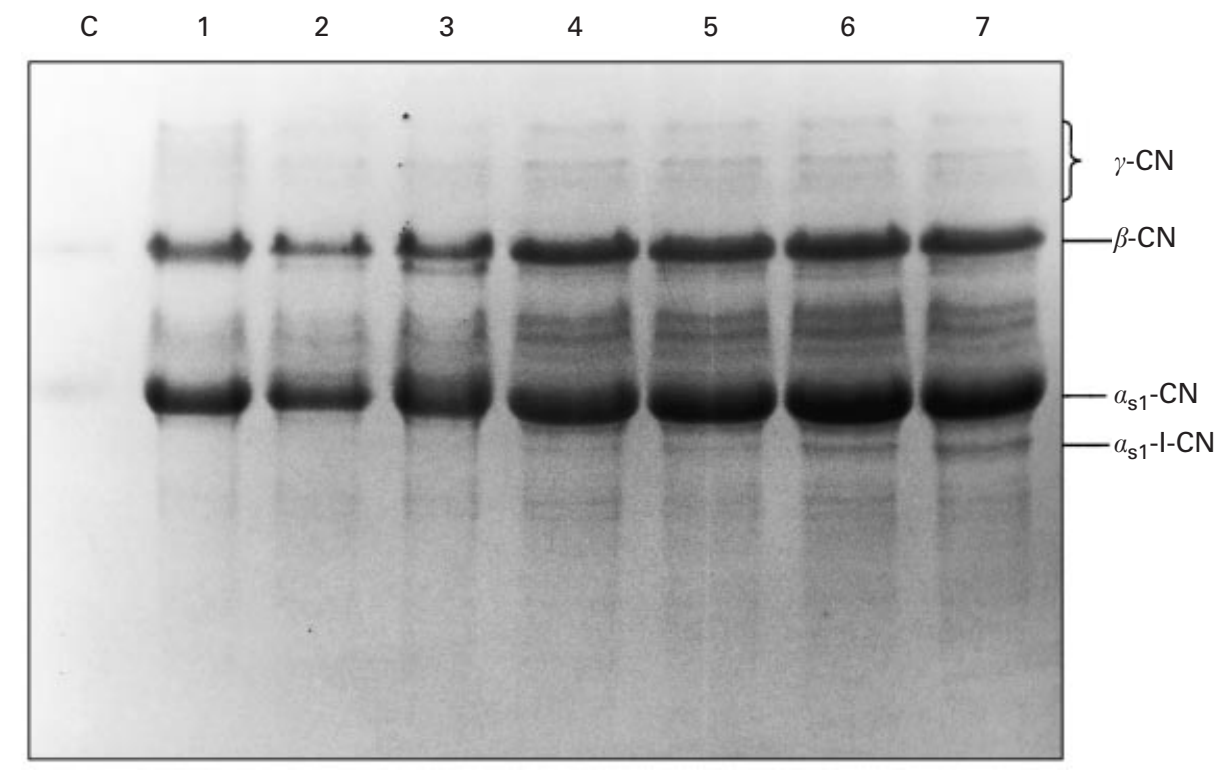

Fig. 3. Urea-PAGE of caseinate (C), the micro-filtered skim milk (lane 1) and the insoluble fraction of the curd at different steps of the cheese-making: cutting (lane 2), drawing (lane 3), first turn (lane 4), second turn (lane 5), third turn (lane 6) and demoulding (lane 7). The location of casein is given.

dependence with exponent values of $1 \cdot 38,1 \cdot 12$ and $1 \cdot 11$, respectively $(P<0.002$ for linear regression of $\log -\log$ ). Values for $\exp G^{\prime}, \exp G^{\prime \prime}$ and the loss angles were plotted versus $\mathrm{pH}$ at each turn (Fig. 2); a convex graph was obtained, with a maximum around $\mathrm{pH} 5 \cdot 2$.

\section{Biochemical analysis}

As a consequence of the high quantity of whey expelled during the drainage, the TS of the curd increased during cheese manufacture (Table 2). In parallel, the mineral content of the curd (expressed in $\mathrm{mg} / \mathrm{kg}$ curd, i.e. in matrix and aqueous phase) and its corresponding aqueous phases (expressed in $\mathrm{mg} / \mathrm{kg}$ of aqueous phase) increased (Table 2). Firstly, the increase observed in the curd was related to the expulsion of whey that induced a concentration of the minerals in the casein matrix. Secondly, the decrease of $\mathrm{pH}$ induced a solubilization of micellar calcium phosphate, contributing to the increased mineral contents in the aqueous phase of the curd. Due to the low proportion of aqueous phase within the curd at the end of the drainage, the concentration of minerals in the aqueous phase was higher than the concentration in the curd. The rate of inversion of these concentration values between the curd and corresponding aqueous phase was slower for minerals that were strongly bound to the casein matrix (calcium, magnesium and inorganic phosphate), than for those free in solution (sodium and potassium).

Extensive whey drainage led to concentration of TN in the curd. SN and NPN amounts also increased due to the proteolysis of casein (Table 2). Moreover the amount of TN and TN-SN (corresponding primarily to intact casein, $\alpha_{\mathrm{s} 1}$-I-casein and $\gamma$-caseins) also increased because the amount of SN was low compared with TN. As observed by urea- PAGE, the intensity of $\alpha_{\mathrm{S} 1}{ }^{-}$and $\beta$-casein bands increased in the insoluble fraction of the curd (Fig. 3). This result showed that the proportion of casein to TN increased in the curd throughout drainage. The concentration of $\alpha_{\mathrm{s} 1^{-}}$ and $\beta$-casein was visible although their concomitant degradation was evidenced by 
the appearance, from the second turn, of bands with electrophoretic mobility corresponding to that of $\alpha_{\mathrm{s} 1}-\mathrm{I}$ - and $\gamma$-casein, respectively.

\section{DISCUSSION}

Structure development of a soft cheese curd begins with the formation of aggregated micellar particles resulting from the rearrangement of casein micelles subsequent to the action of chymosin on $\kappa$-casein, the acidification that solubilized minerals, and the drainage of the curd that concentrates solids. Using scanning electronic microscopy, we visualized casein particles agglomerated in clusters within the curd at the first turn, i.e. $1.5 \mathrm{~h}$ after renneting. At this stage, $76 \%$ of the whey had already been expelled. The subsequent acidification and mineral solubilization therefore proceeded within an almost drained curd, because only about $15 \%$ of whey was subsequently expelled before demoulding.

At the first turn, a slight $\mathrm{pH}$-induced solubilization of micellar calcium phosphate, magnesium and citrate ions from the casein matrix to the aqueous phase has begun (Pyne \& McGann, 1960). About $80 \%$ of the calcium and $75 \%$ of the inorganic phosphate were still associated with the casein matrix. Consecutive to acidification, ionic strength of the aqueous phase increased (Brulé et al. 1974; van Hooydonk et al. 1986; Visser et al. 1986; Dalgleish \& Law, 1989; Le Graët \& Brulé, 1993; Famelart et al. 1996; Gastaldi et al. 1996; Gaucheron et al. 1996). In the soft cheese curd model, casein concentration throughout drainage slowed the $\mathrm{pH}$-induced solubilization of minerals compared with that observed in milk (Le Graët \& Brulé, 1993). The high retention of minerals in the curd has probable implications for the structure of the casein matrix. The retention of calcium ions in the curd occurred probably by binding to the casein. The two consequences of this binding were a reduced negative charge on the casein and a more compact particle structure due to connections within the casein structure by this divalent cation.

At the second turn, particles within clusters rearranged into chains but the micelle-based structure was still visible. As a consequence of the decrease in $\mathrm{pH}$, the negative charge of caseins was reduced (Lomholt \& Qvist, 1999), and micellar calcium phosphate moved out of the casein strands to the aqueous phase. Both phenomena might strengthen hydrophobic interactions at the expense of calcium bridge interactions and lead to the observed thickening of the strands during subsequent drainage. It is noteworthy that at this step, about 60 and $55 \%$ of the total calcium and inorganic phosphate were still associated with the casein matrix. These values are higher than those obtained during milk acidification (without drainage), as it is generally admitted that at $\mathrm{pH} 5 \cdot 2$ all inorganic phosphate is solubilized (van Hooydonk et al. 1986; Visser et al. 1986; Dalgleish \& Law, 1989; Le Graët \& Brulé, 1993; Gaucheron et al. 1996; Le Graët \& Gaucheron, 1999). Indeed, as the acidification occurred during drainage (resulting in casein concentration), a shift of mineral solubilization towards lower $\mathrm{pH}$ has been observed (Gastaldi et al. 1997; Le Graët \& Gaucheron, 1999), that corresponds probably to a large and rapid increase in the ion activity product of calcium phosphate salts in the aqueous phase of the curd.

Another interesting way to obtain structural insights in the casein matrix is to determine its composition. Intact caseins as well as $\alpha_{\mathrm{s} 1}$-I-casein and $\gamma$-caseins accumulated in the curd during drainage. The appearance, from the second turn, of $\alpha_{\mathrm{s} 1}$-I-casein in the insoluble fraction of curd demonstrated the continuous action of chymosin and indicated that $\alpha_{\mathrm{s} 1}$-I-casein is a constitutive element of the casein 
matrix. Concomitantly the $\alpha_{\mathrm{s} 1}-\mathrm{CN} f(1-23)$ has been identified in the corresponding whey (Boutrou et al. 2001). The appearance of $\alpha \mathrm{s}_{1}$-I-casein may facilitate rearrangement of the remaining casein particles possibly through hydrophobic or electrostatic interactions, and thus prepare the change of texture that happens during the ripening of soft cheese. De Jong (1976) showed that the change in consistency during ripening of soft cheese was caused by the breakdown of $\alpha_{\mathrm{s} 1}$-casein, while the $\beta$-casein remained almost unchanged. According to Noomen (1977) the weakening of the soft cheese body was closely related to the protein breakdown under the existing conditions in the cheese, especially the $\mathrm{pH}$. This was confirmed by Vassal et al. (1986). Changes in matrix composition can explain the initial increase of loss tangent at the second turn. Indeed, the loss tangent and the exponents of the modulus - frequency relation were maximal at $\mathrm{pH} 5 \cdot 2$. Similar trends were observed in many studies on rennet gels (Roefs, 1986) and on young Gouda cheese (Luyten, 1988) and this has been related to the maximum of casein voluminosity. Tan $\delta$ can increase with the micellar calcium phosphate solubilization. Zoon et al. (1988b) reported that reducing the concentration of micellar calcium phosphate below half the amount present in milk (i.e. pH $5 \cdot 7$ according to van Hooydonk et al. (1986), and $\mathrm{pH} 5 \cdot 2$ in our study) leads to an increase in tan $\delta$.

From the third turn to the demoulding, the rearrangement of casein particles continued towards a continuous matrix. The acidification rate slowed and the rheological properties of the curd, especially strength, Young's modulus and loss modulus greatly increased. Studying the relationship between the firmness or moduli and protein concentration is relevant because this relationship characterizes the organisation of the network and its changes with time. Many authors reported an increase in firmness exponentially related to casein or nitrogen or solid content, with an exponent value (exp) greater than 1 for acid gels (Harwalkar \& Kalab, 1980; exp $=2 \cdot 6$ ), for rennet gels (Zoon et al. $1988 a$; $\exp =2 \cdot 4$ for gels aged for $7 \mathrm{~h}$ ) and for cheeses (De Jong, 1978; $\exp =5 \cdot 7$ for Meshanger experimental ripened cheese; Luyten, 1988; $\exp =10$ for fat Gouda cheese from 1 week to 13 months ripening). According to Luyten (1988), this effect is due, first to the increase in concentration of the stress carrying component of cheese and second, to the lower freedom of the less swollen particles with a lower moisture. The exponent values of the power law were low compared to cited values (Roefs, 1986; Zoon et al. 1988a), but it means that in all these gels, the number of stress carrying strands was not strictly proportional to the number of particles. This was probably due to the rearrangement of casein particles during the drainage.

At the end of drainage, $20 \%$ of calcium and inorganic phosphate was still associated with the casein matrix. Such an incomplete solubilization showed that in the structure development of soft cheese curd, the role of minerals is probably underestimated and even at $\mathrm{pH} 4 \cdot 8$, they can still participate in the structure of the curd by formation of bridges between two negative sites on casein molecules (organic phosphate of phosphoserine, carboxyl groups of acid amino acid) and/or inorganic phosphate. From this point of view, to determine the nature of the calcium phosphate still associated with the casein matrix was of major interest. The relatively constant ion activity product of the calcium phosphate salt suggested that it was probably close to dicalcium phosphate (Table 2).

This work has investigated the structure development of the casein matrix of a fat-free soft cheese curd model during drainage. The cheese curd thus forms the basis of the cheese, which is later modified by salting and ripening. Further studies are required to include the role of fat in the structure of soft cheese curd. The effect of 
salting and the presence of other micro-organisms during ripening should also be considered.

We are grateful to J. Berrier for microscopic observations and to J. Fauquant for microfiltration of milk.

\section{REFERENCES}

Andrews, A. T. 1983 Proteinases in normal bovine milk and their action on caseins. Journal of Dairy Research $5045-55$

Boutrou, R., Mollé, D. \& Léonil, J. 2001 Action of the lactococcal proteinase during Camembert-type curd making. International Dairy Journal 11 347-354

Boutrou, R., Sepulchre, A., Pitel, G., Durier, C., Vassal, L., Gripon, J. C. \& Monnet, V. 1998 Lactococcal lysis and curd proteolysis: two predictable events important for the development of cheese flavour. International Dairy Journal 8 609-616

Brulé, G., Maubois, J. L. \& Fauquant, J. 1974 Contents of mineral elements in products from ultrafiltered milk. Le lait 54 600-615

Chaplin, L. C. 1984 Studies on micellar calcium phosphate: composition and apparent solubility product in milk over a wide pH range. Journal of Dairy Research 51 251-257

Dalgleish, D. G. \& Law, A. J. R. 1989 pH-induced dissociation of bovine casein micelles. II. Mineral solubilization and its relation to casein release. Journal of Dairy Research 56 727-735

De Jong, L. 1976 Protein breakdown in soft cheese and its relation to consistency. 1. Proteolysis and consistency of 'Noorhollandse Meshanger' cheese. Netherlands Milk and Dairy Journal $30242-253$

De Jong, L. 1978 The influence of the moisture content on the consistency and protein breakdown of cheese. Netherlands Milk and Dairy Journal 32 1-14

Emmons, D. B., Kalab, M. \& Larmond, E. 1980 Milk gel structure. X. Texture and microstructure in Cheddar cheese made from whole milk and from homogenized low-fat milk. Journal of Texture Studies 11 15-34

Famelart, M. H., Lepesant, F., Gaucheron, F., Le Graët, Y. \& Schuck, P. 1996 pH-induced physicochemical modifications of native phosphocaseinate suspensions: influence of aqueous phase. Le lait 76 445-460

Gastaldi, E., Lagaude, A., Marchesseau, S. \& Tarodo de la Fuente, B. 1997 Acid milk gel formation as affected by total solids content. Journal of Food Science 62 671-675

Gastaldi, E., Lagaude, A. \& Tarodo de la Fuente, B. 1996 Micellar transition state in casein between pH $5 \cdot 5$ and 5.0. Journal of Food Science $6159-68$

Gaucheron, F., Le Graët, Y., Piot, M. \& Boyaval, E. 1996 Determination of anions of milk by ion chromatography. Le lait $76433-443$

Gripon, J. C., Desmazeaud, M., le Bars, D. \& Bergère, J. L. 1975 Role of micro-organisms and their enzymes in cheese ripening. II. Effect of commercial rennet. Le lait $\mathbf{5 5} 502-516$

Haque, Z. U., Kucukoner, E. \& Aryana, K. J. 1997 Aging-induced changes in populations of lactococci, lactobacilli, and aerobic microorganisms in low-fat and full-fat Cheddar cheese. Journal of Food Protection $\mathbf{6 0}$ $1095-1098$

Harwalkar, V. R. \& Kalab, M. 1980 Milk gel structure. XI. Electron microscopy of glucoco-delta-lactoneinduced skim milk gels. Journal of Texture Studies $1135-49$

Holt, C. 1982 Inorganic constituents of milk. III. The colloidal calcium phosphate of cow's milk. Journal of Dairy Research $4929-38$

Holt, C., Dalgleish, D. G. \& Jenness, R. 1981 Calculation of the ion equilibria in milk diffusate and comparison with experiment. Analytical Biochemistry 113 154-163

Horne, D. S., Banks, J. M., Leaver, J. \& Law, A. J. R. 1993 Dynamic mechanical spectroscopy of Cheddar cheese. International Dairy Congress International Dairy Federation seminar, Cork: 507-512

International Dairy Federation 1982 Cheese and processed cheese. Determination of the total solids content. Brussels: IDF (FIL-IDF Standard 4A)

Kalab, M. 1978 Milk gel structure. VIII. Effect of drying on the scanning electron microscopy of some dairy products. Milchwissenschaft 33 353-358

Kalab, M. 1979 Scanning electron microscopy of dairy products : an overview. Scanning Electron Microscopy $3261-272$

Kalab, M., Allan-Wojtas, P. \& Phipps-Todd, B. E. 1983 Development of microstructure in set-style nonfat yoghurt. A review. Food Microstructure 2 51-66

Kfoury, M., Mpagana, M. \& Hardy, J. 1989 Influence de l'affinage sur les propriétés rhéologiques du camembert et du saint-paulin. Le lait $69137-149$

Le Graët, Y. \& Brulé, G. 1993 [Effects of pH and ionic strength on mineral balance of milk]. Le lait 73 51-60

Le Graët, Y. \& Gaucheron, F. 1999 pH-induced solubilization of minerals from casein micelles: influence of casein concentration and ionic strength. Journal of Dairy Research 66 215-224

Lomholt, S. T. \& Qvist, K. B. 1999 The formation of cheese curd. In Technology of Cheesemaking, Chp. 3, pp. 66-98 (Ed. B. A. Law). Sheffield: Sheffield Academic Press

Luyten, H. 1988 The rheological and fracture properties of gouda cheese, Ph.D. thesis, pp. 1-223. Agricultural University, Wageningen 


\section{8}

\section{R. Boutrou and others}

McMahon, D. J. \& Oberg, C. J. 1999 Deconstructing Mozzarella. Dairy International Industries 7 23-26

Mietton, B., Desmazeaud, M., de Roissart, H. \& Weber, F. 1994 Transformation du lait en fromage. In Bactéries Lactiques, IV-3, pp. 55-133 (Eds H. de Roissart and F. M. Luquet). Uriage: Lorica

Morgan, F., Henry, G., Le Graët, Y., Mollé, D., Léonil, J. \& Bouhallab, S. 1999 Resistance of $\beta$-lactoglobulinbound lactose to the hydrolysis by $\beta$-galactosidase. International Dairy Journal 9 813-816

Morris, H. A., Holt, C., Brooker, B. E., Banks, J. M. \& Manson, W. 1988 Inorganic constituents of cheese: analysis of juice from one-month-old Cheddar cheese and the use of light and electron microscopy to characterize the crystalline phases. Journal of Dairy Research 55 255-268

Mpagana, M. \& Hardy, J. 1986 Effect of salting on some rheological properties of fresh camembert cheese as measured by uniaxial compression. Milchwissenschaft 41 210-213

Noomen, A. 1977 Noordhollandse Meshanger cheese: a model for research on cheese ripening. 2. The ripening of the cheese. Netherlands Milk and Dairy Journal 31 75-102

Oberg, C. J., McManus, W. R. \& McMahon, D. J. 1993 Microstructure of Mozzarella cheese during manufacture. Food Structure 12 251-258

Pyne, G. T. \& McGann, T. C. A. 1960 The colloidal phosphate of milk. II. Influence of citrate. Journal of Dairy Research 27 9-17

Roefs, S. P. F. M. 1986 Structure of acid casein gels, Ph.D. thesis, Agricultural University, Wageningen

Rousseau, M. \& Le Gallo, C. 1990 Etude de la structure de l'Emmental au cours de la fabrication par la technique de microscopie électronique à balayage. Le lait $7055-66$

Solorza, F. J. \& Bell, A. E. 1995 Effect of calcium, fat and total solids on the rheology of a model soft cheese system. Journal of the Society of Dairy Technology 48 133-139

Tamime, A. Y., Kalab, M. \& Davies, G. 1984 Microstructure of set-style yoghurt manufactured from cow's milk fortified by various methods. Food Microstructure 3 83-92

Trouvé, E., Maubois, J. L., Piot, M., Madec, M. N., Fauquant, J., Rouault, A., Tabard, J. \& Brinkman, G. 1991 Retention of various microbial species during purification of milk using cross-flow microfiltration. Le lait 71 1-13

van Hooydonk, A. C. M., Hagedoorn, H. G. \& Boerrigter, I. J. 1986 pH-induced physico-chemical changes of casein micelles in milk and their effect on renneting. 1. Effect of acidification on physico-chemical properties. Netherlands Milk and Dairy Journal 40 281-296

Vassal, L., Monnet, V., le Bars, D., Roux, C. \& Gripon, J. C. 1986 Relation entre le pH, la composition chimique et la texture des fromages de type Camembert. Le lait 66 341-351

Visser, J., Minihan, A., Smits, P., Tjan, S. B. \& Heertje, I. 1986 Effects of $\mathrm{pH}$ and temperature on the milk salt system. Netherlands Milk and Dairy Journal 40 351-368

Zoon, P., van Vliet, T. \& Walstra, P. 1988a Rheological properties of rennet-induced skim milk gels. 1. Introduction. Netherlands Milk and Dairy Journal 42 249-269

Zoon, P., van Vliet, T. \& Walstra, P. $1988 b$ Rheological properties of rennet-induced skim milk gels. 3. The effect of calcium and phosphate. Netherlands Milk and Dairy Journal 42 295-312 